\title{
VERDADE E FALSIDADE NA SUMA TEOLÓGICA: UMA LEITURA ACERCA DO LUGAR DA POESIA NA TRADIÇÃO ESCOLÁSTICA
}

Fabio Galera ${ }^{1}$

\begin{abstract}
RESUMO
O propósito deste trabalho é investigar o lugar que foi reservado para a poesia ou o dizer ficcional no âmbito da tradição escolástica. Compreendendo que a diferença fundamental entre o dizer poético e o dizer filosófico está essencialmente na relação que ambos possuem com a noção de verdade, a pesquisa dirige o olhar para o pensamento medieval como sendo uma etapa importante para a sedimentação dessa relação com a verdade. A reflexão aqui proposta pretende acompanhar os passos mais significativos da argumentação tomasiana acerca da questão da verdade e da falsidade na Suma Teológica, com o intuito de mapear os princípios que irão fundamentar e sedimentar a separação epistêmica entre o dizer poético e o dizer filosófico. Assim, tomaremos como objeto de análise, as questões dezesseis e dezessete da primeira parte da Suma Teológica de Tomás de Aquino, em que são abordados os temas da Verdade e da Falsidade respectivamente.
\end{abstract}

Palavras-chave: Tomás de Aquino. Suma Teológica. Verdade. Verdade Poética. Verdade Filosófica. Falsidade.

\begin{abstract}
The purpose of this work is to investigate the scope reserved for poetic discourse in scholastic tradition. Understanding that the fundamental difference between poetic saying and philosophical saying is essentially in the relationship that both have with the notion of truth, the research directs its attention to medieval thought, being it an important phase for the consolidation of such relationship. Our reflection intends to accompany the fundamental steps of the Thomasian argument about the Question of truth and falsehood, in Summa Theologica. Thus, we map the principles that will support and consolidate the epistemic separation between poetic and philosophical saying. To this end, we will analyze questions sixteen and seventeen of the first part of the Summa of Thomas Aquinas, in which the themes of Truth and Falsehood are discussed.
\end{abstract}

Keywords: Thomas Aquinas. Summa Theologica. Truth. Poetic Truth. Philosophical Truth. Falsehood.

\footnotetext{
${ }^{1}$ Doutor em Ciência da Literatura - UFRJ e Doutorando em Filosofia na UFRJ.

E-mail: fabiogalera@yahoo.com.br.
} 


\section{"É, e não é. O senhor ache e não ache. Tudo é e não é..." \\ Guimarães Rosa \\ Grande Sertão: Veredas}

\section{A Questão da Verdade na Suma Teológica}

\section{Exposição da Questão da Verdade}

Para orientar nossa exposição, cumpre apresentar a estrutura ${ }^{2}$ da questão da verdade, bem como seu encadeamento básico em vista da argumentação defendida em cada artigo da Suma Teológica. Ao abordar o tema da verdade, a questão dezesseis da Suma Teológica está estruturada em torno de oito perguntas, desenvolvidas em seus respectivos artigos, tratadas segundo o método escolástico das questões disputadas. Eis a síntese da questão: artigo $1^{\circ}$. busca investigar onde está a verdade, concluindo que está principalmente no intelecto e secundariamente nas coisas; artigo $2^{o}$. estando a verdade fundamentalmente no intelecto, situa-se especificamente no intelecto que compõe e divide, o intelecto passivo, manifestando-se através da expressão dos juízos contidos nos enunciados; artigo $3^{o}$. para garantir a integração do plano intelectivo e do plano real, Aquino irá defender a tese de que a razão de verdadeiro e o ente são convertíveis, para que seja ratificada a possibilidade de identificação entre os planos real e intelectual/intencional, afirmando o real e o verdadeiro como sendo noções de mesma extensão; artigo $4^{\circ}$. Aquino coloca em questão se a verdade é anterior ao bem, e assim defende uma escala de primazia, lógica e por isso formal: em primeiro lugar está o ente, em segundo lugar a razão de verdadeiro, em terceiro o bem; artigo $5^{\circ}$. será defendida a tese teológica de que não só a verdade está em Deus mas que ele é a própria verdade, suprema e primeira, enquanto intelecto divino, transcendendo o caráter particular ou individual do intelecto humano; artigo $6^{o}$. eleva e ratifica a verdade que é Deus, enquanto intelecto divino, como sendo causa da verdade de toda e qualquer coisa, subordinando toda

\footnotetext{
${ }^{2}$ Vale destacar que a ordem geral dos artigos repete sempre a mesma organização: 1. Em primeiro lugar é apresentada uma afirmação hipotética; 2. Em seguida figuram as objeções à afirmação inicial acerca do tema proposto, variando em número; 3 . Aquino dá uma resposta geral acerca do tema, considerando a afirmação inicial e apresentando seu parecer; 4 . Em seguida para fechar o artigo, Aquino dá uma resposta específica para cada objeção apresentada no início do artigo, solucionando os possíveis erros e incompreensões do que se defende nas objeções.
} 
verdade à verdade divina; artigo $7^{\circ}$. defende a eternidade da verdade própria ao intelecto divino, sendo esta não-criada; artigo $8^{\circ}$. a verdade do intelecto divino é imutável, é e será igual a si mesma sempre. Em síntese, a questão irá afirmar que: a verdade está no intelecto humano (1), por identificar-se com a verdade do intelecto divino (5), totalizando a verdade de todas as coisas (6), de todos os entes corpóreos (3), pois o ente ${ }^{3}$ é anterior à verdade e ao próprio bem (4) - o que justifica o realismo tomasiano -, sendo verdade desde sempre (7) e sem chance de algum dia deixar de ser (8), verdade está que só poderá ser acessada caso seja perseguida através do rigor da lógica proposicional (2) e da fundamentação teológica.

Agora devemos seguir os passos do desenvolvimento da compreensão de verdade na Suma Teológica, expondo sua argumentação, para compreendermos sua relação com a poesia, isto é, compreender como a delimitação da verdade demarca uma posição desfavorável para a poesia. A primeira pergunta, contida no primeiro artigo já inicia com uma decisão importante, que irá estruturar toda a discussão subsequente - inclusive para a questão da falsidade, que será tratada adiante. $A$ verdade se encontra na coisa, ou apenas no intelecto? (AQUINO, 2001, p. 357) A própria pergunta já determina sua resolução. Ou a verdade está na coisa, ou no intelecto, ou em ambos. Não aparece na pergunta uma terceira opção, uma terceira alternativa está sempre excluída na lógica formal ${ }^{4}$. Esta pergunta talvez seja a mais importante para o que será fundamentado na questão, pois, diante das duas alternativas propostas, coisa e/ou intelecto, já está decidido que a verdade só ${ }^{3}$ Conforme o Vocabulário assinado pela Professora Marie-Joseph Nicolas, na edição aqui
consultada, AQUINO, Tomás. Suma Teológica. Volume I. São Paulo: Edições Loyola,
2001, pp. 69-102, na terminologia de Tomás de Aquino, ente (ens) é um modo de dizer o
ser. Ele distingue o ser através das palavras latinas ens e esse. Ens, ente, é "a coisa existen-
te, aquilo que existe aquilo que exerce o ato de existir ou que é concebido como podendo
exercê-lo", o que pode também ser chamado de "substância, sujeito, supósito" p. 97. As-
sim, ente, coisa, real, são palavras que não poderiam ser ditas a partir da linguagem poética,
a menos que sejam mediadas pelo conceito aristotélico da verossimilhança. ARISTÓTE-
LES. Poética. Tradução de Eudoro de Sousa. In: Coleção Os Pensadores. Aristóteles. Orga-
nização de José Américo Motta Pessanha. São Paulo: Abril S.A. Cultural, 1984 .
${ }^{4}$ Conforme Aristóteles, na Metafísica, no Livro 4, Capítulo 7, 1011b, acerca da Demons-
tração do princípio do terceiro excluído por via de refutação, "não é possível que exista um
terceiro médio entre os contraditórios, mas é necessário ou afirmar ou negar, do mesmo ob-
jeto um só dos contraditórios, qualquer que seja ele. Isso é evidente pela própria definição
do verdadeiro e do falso: falso é dizer que o ser não é ou que o não-ser é; verdadeiro é dizer
que o ser é e que o não-ser não é. Consequentemente, quem diz de uma coisa que é ou que
não é, ou dirá o verdadeiro ou dirá o falso. Mas se existisse um termo médio entre os dois
contraditórios nem do ser nem do não-ser poder-se-ia dizer que ou é ou não é", ARISTÓ-
TELES. Metafísica. Tradução de Giovanni Reale. São Paulo: Edições Loyola, 2002, p. 179 . 
poderá ser encontrada em um dos dois termos. Estes termos são apresentados como as duas instâncias possíveis para a verdade. Cabe aqui uma retomada, para nos entendermos acerca do sentido de coisa e intelecto na formulação tomasiana da verdade. E ainda como o intelecto interage com a coisa, visto que está de início pressuposta a diferença ontológica entre os dois termos, cada um pertencendo a uma natureza diversa.

No estudo do Vocabulário da Suma (NICOLAS, 2001, pp. 69-102), coisa é o próprio real, é aquilo que o pensamento, ou melhor, o intelecto conhece e pode conhecer (NICOLAS, 2001, pp. 76-77), as coisas reais, as coisas corpóreas e materiais. Mas o real não é absolutamente o sensível, corpóreo e material. Também é constitutivo do real aquilo que o intelecto abstrai das coisas corpóreas e matérias - apesar da primazia do real, da coisa, dos entes se manifestar pelo seu aspecto corpóreo e material. Isso porque é necessário que o conhecido, a coisa, o real, esteja também naquele que conhece, no intelecto. Isso significa que o real deve estar contido no intelecto, tal como sua natureza própria exige que o seja: o real deve estar no intelecto de modo imaterial e incorpóreo $o^{5}$ posto que real é corpóreo e material. Assim, o intelecto conhece o real imaterialmente e não de modo sensível, isto é, sua materialidade. $\mathrm{O}$ intelecto conhece de fato o real pelo que há nele de imaterial, sua espécie, sua forma, seu princípio de ordenação e organização necessária, suas causas. $\mathrm{O}$ intelecto é compreendido como uma faculdade espiritual que dá a conhecer o universal, o imaterial, a essência das coisas (NICOLAS, 2001, p. 85).

Tomás de Aquino distingue nessa faculdade, sua dimensão ativa e passiva. O intelecto agente é a parte do intelecto que é capaz de abstrair, isto é, separar "o universal inteligível do singular sensível” (NICOLAS, 2001, p. 85). É através da abstração que o intelecto depreende "da realidade sensível que lhe é oferecida pelos sentidos - o inteligível que esta contém em potência, ou seja, a realidade universal, que dá origem ao conceito" (NICOLAS, 2001, p. 71). No âmbito da abstração, chama-se abstração total aquela que

\footnotetext{
${ }^{5}$ Conforme Tomás de Aquino, "o intelecto recebe as imagens dos corpos materiais e mutáveis sob um modo imaterial e imutável, à sua maneira, pois, o que é recebido está naquele que recebe segundo o modo de quem recebe. - Deve-se dizer, portanto, que a alma conhece os corpos por meio do intelecto, por um conhecimento imaterial, universal e necessário", AQUINO, T. 2002. Suma Teológica. Volume II. São Paulo: Edições Loyola, p. 499.
} 
depreende o universal, apresentando uma realidade inteligível, ainda que sua representação linguística designe uma realidade existente nas coisas individuais, nos entes, como se dá na relação entre o gênero animal (inteligível) e suas ocorrências possíveis, entre a espécie humana e os homens individuais e existentes. Esta é a abstração própria ao intelecto agente. Nesta abstração, o real ainda está articulado com a dimensão corpórea, material, entitativa. Porém, há ainda a abstração formal, capaz de separar de um objeto concreto existente o seu universal, sua essência, constituindo-se em uma elaboração mental inteiramente abstrata, destacando o que determina o objeto como tal, tratando-o isoladamente como realidade inteligível, como "princípio de inteligibilidade daquilo que existe" (NICOLAS, 2001, p. 71), a humanidade, a animalidade, de modo independente dos entes em ato, o seu ser. Esta última abstração seria própria ao intelecto passivo, que é, na verdade, a "atividade suprema e específica do homem, que é o ato do pensamento" (NICOLAS, 2001, p. 85). Ele é passivo, por que depende da abstração total realizada no âmbito do intelecto agente. $\mathrm{O}$ intelecto passivo será aquele capaz de se expressar e elaborar juízos, de conhecer de fato as coisas, o real, a verdade. Isso porque o que pode ser conhecido pelo intelecto só o é através da atividade de julgar, de compor e dividir ${ }^{6}$. Nele, no intelecto passivo, temos o agravamento da faculdade intelectiva, através da abstração formal, pois "o intelecto que abstrai a espécie, não só da matéria, mas também das condições singulares e materiais, conhece mais perfeitamente do que os sentidos, que recebem a forma da coisa conhecida sem matéria", e "entre os intelectos, um é tanto mais perfeito, quanto mais imaterial" (AQUINO, 2002, p. 503).

\section{$A$ relação entre intellectus et rei}

O que acabamos de ver seria uma síntese bastante breve e superficial da relação entre coisa e intelecto no pensamento tomasiano, bem como da elaboração das etapas do conhecer. Isto já será suficiente para podermos entrar na pergunta acerca da verdade, a qual deve decidir se a verdade está nas coisas, no intelecto, ou em ambos, seguindo a ordem das perguntas contidas

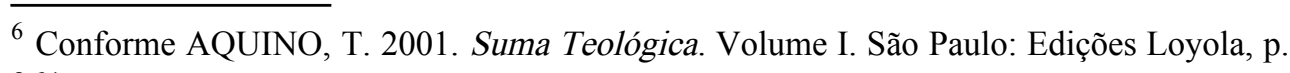
361. 
na questão da verdade. Considerando apenas a pergunta, já está pressuposta a separação/relação entre coisa e intelecto, ou seja, entre homem e real. É claro que tal relação não é colocada em questão. Seu pensamento toma como pressuposta a separação. Essa separação desempenha um papel fundamental na elaboração da verdade para Tomás de Aquino, pois é a partir dela, da separação mesma, que ele irá sustentar todo o seu sistema cognoscente, apoiando-se na separação intelecto-coisa - que modernamente será equivalente à separação entre sujeito-objeto -, de tal modo que se estruture o conceito de verdade. Esse é o ponto de partida da questão: ou está na coisa ou está no intelecto. De modo algum essa relação entra em questão. De modo algum a relação é apresentada como uma questão. A própria ideia de adequação ou concordância, princípios básicos da definição de verdade assumida por Tomás de Aquino, pressupõe a relação/separação entre coisa e intelecto, para que haja a confrontação entre intelecto e coisa. Mas como podemos compreender essa relação de coisa e intelecto em Tomás de Aquino?

Tomás de Aquino compara o conhecer com o apetite no primeiro artigo. A atividade intelectiva se contrapõe à atividade sensitiva, ou seja, são atividades que se dão em dimensões distintas, separadas, ainda que articuladas/relacionadas e indissociáveis para Tomás de Aquino - conforme se definiria seu realismo bem como a ideia de unidade entre corpo e alma ${ }^{7}$. Aceita a possibilidade de comparação, pressuposta também a separação ontológica entre real e ideal ${ }^{8}$, intelecto e coisa, Aquino afirma que o termo do apetite, o bem, está nas coisas, assim como o termo do conhecer, a verdade, está no intelecto. Termo parece dizer aí consumação, realização. Assim, o apetite encontra sua consumação nas coisas, encontrando o bem do apetite nas coisas, da mesma forma que o termo do conhecer encontra sua realização no intelecto 9 , com a verdade. Deste modo, o conhecer deve dirigir-se ao intelecto. É justamente nesse ponto que vemos um impasse: se o conhecer encontrará a verdade ou o verdadeiro das coisas apenas no intelecto, como esse procedimento retomará o contato com a coisa, com o real? Sem retomar a relação

\footnotetext{
${ }^{7}$ Conferir A união da alma com o corpo, AQUINO, 2002, pp. 371-401.

${ }^{8}$ De acordo com Heidegger, o problema da questão da verdade pode decorrer justamente daí: "será que o descaminho da questão consiste em seu ponto de partida, ou seja, na separação ontologicamente não esclarecida entre real e ideal?”, HEIDEGGER, 2008, p. 287.

${ }^{9}$ Conforme Tomás de Aquino, "chamamos bem àquilo a que tende o apetite, chamamos verdade àquilo a que tende o intelecto", AQUINO, 2001, p. 358.
} 
do intelecto com a coisa, o verdadeiro estará circunscrito exclusivamente ao âmbito do intelecto, que conhece intelectualmente e de modo imaterial. Com isso não seria possível demonstrar a verdade ou a falsidade das coisas, do real. Estaria o verdadeiro aprisionado no intelecto? Como resolver essa aporia? Muito simples: reestabelecendo a relação entre real e intelecto. Resta verificar como.

O apetite é uma faculdade do homem, isto é, da alma humana. De algum modo o apetite passa da alma para as coisas, para o real, encontrando seu termo, sua consumação no real. Pois, o apetite, para encontrar sua consumação, precisa passar, isto é, precisa se transferir; o apetite precisa transpor a circunscrição do intelecto, de algum modo separado do real, em direção às coisas, visto que a coisa, isto é, o real atrai o apetite, é para onde o apetite tende. A mesma lógica deverá servir para se entender a relação da verdade no intelecto: a intelecção, ou seja, o conhecer passa do intelecto para a coisa e, igualmente, a coisa abstrai-se para o intelecto. Há, portanto, entre real e intelecto uma via de mão dupla. A verdade está no intelecto, na medida em que o intelecto abstrai e conhece a coisa, sua causa, seu universal, sua espécie, sua forma, constituindo uma imagem, elaborada pela imaginação, no intelecto, a partir da impressão da coisa nos sentidos, adequando a materialidade da coisa ao intelecto - a impressão parte da coisa para o intelecto $^{10}$, para que este possa conhecer as coisas de modo imaterial. No sentido inverso, a razão de verdade, o princípio de inteligibilidade, que está no intelecto, do mesmo modo também passa do intelecto para a coisa, para com ela, com a coisa, se adequar, se conformar. É somente aí que se dá a verifi-

\footnotetext{
10 Conforme Aquino, “O objeto cognoscível é, como foi dito, proporcionado à potência cognoscitiva. Ora há três graus da potência cognoscitiva. Uma é ato de um órgão corporal; é o sentido. Por isso, o objeto de toda potência sensível é a forma conforme existe em uma matéria corporal. Sendo essa matéria princípio da individuação, toda potência sensível só conhece os particulares. - Outra potência cognoscitiva não é ato de um órgão corporal e não está unida de nenhuma maneira à matéria corporal; é o intelecto angélico. Por isso o objeto dessa potência cognoscitiva é a forma subsistente sem a matéria. Embora conheçam as coisas materiais, não as conhecem senão vendo-as nas imateriais, a saber, em si mesmos ou em Deus. - $O$ intelecto humano se põe no meio: não é ato de um órgão, mas é uma potência da alma, que é forma do corpo, como ficou demonstrado. Por isso, é sua propriedade conhecer a forma que existe individualizada em uma matéria corporal, mas não essa forma enquanto está em tal matéria. Ora, conhecer dessa maneira, é abstrair a forma da matéria individual, que as representações imaginárias significam. Pode-se, portanto, dizer que nosso intelecto conhece as coisas materiais abstraindo das representações imaginárias. E mediante as coisas materiais consideradas dessa maneira, chegamos a um conhecimento das coisas imateriais, enquanto os anjos ao contrário, conhecem as coisas materiais pelas imateriais.", grifo meu, AQUINO, 2002, pp. 321-326.
} 
cação da semelhança da imagem contida no intelecto, verificando a adequação de coisa e intelecto, do universal, da causalidade. Isso se dá através de juízos contidos nos enunciados sobre o real.

É desta forma que coisa-intelecto, homem-real, reestabelecem sua relação perdida. Melhor, elabora-se abstratamente uma relação predicamental (NICOLAS, 2001, p. 97) e por isso real, durante o ato de conhecimento. Parece que tudo se dá nesse instante em que se elabora o juízo num enunciado. Assim, conforme Aquino, o "verdadeiro, estando no intelecto à medida que ele se conforma com a coisa conhecida é necessário que a razão de verdadeiro passe do intelecto à coisa conhecida, de modo que esta última seja dita verdadeira na medida em que tem alguma relação com o intelecto" (AQUINO, 2001, p. 358). Não fica bem esclarecido aí como se dá essa passagem, esse contato, como se reestabelece a relação. Em outra questão da Suma, ainda na primeira parte, tratando de Por meio do que a alma, unida ao corpo, intelige as coisas corpóreas, Tomás de Aquino afirma que "o ato de conhecer se estende às coisas que estão fora de quem conhece, pois conhecemos também as coisas que estão fora de nós" (AQUINO, 2002, p. 502, grifo meu), fora do intelecto humano.

\section{Causalidade como fundamento da relação entre intelecto e coisa}

Ainda na questão acerca da verdade, primeiro artigo, a análise de Tomás de Aquino procura explicar a relação adequada entre intelecto e coisa para que se dê a verdade. Nesse ponto, o artigo esbarra com a noção de causalidade entre intelecto e coisa, bem como entre intelecto humano e intelecto divino, para que se justifique o caráter seguro ${ }^{11}$ da verdade. As coisas conhecidas se referem ao intelecto humano, ou por si, ou por acidente. Aquino dá o exemplo da relação entre uma casa e seu artífice, ou seja, quem elaborou a

\footnotetext{
${ }^{11}$ Conforme se lê em sua resposta para a questão 84 , as teses opostas àquela defendida por Tomás de Aquino são acusadas por ele de não apresentarem certeza da verdade, por defenderem que o intelecto não é capaz de conhecer através do que é corpóreo. O que está em questão no primeiro artigo a demonstração de que "A alma conhece os corpos pelo intelecto". Segundo Aquino, "os primeiros filósofos que pesquisaram a natureza das coisas pensavam que não havia no mundo senão corpos" e assim "julgaram que não podia haver nenhuma certeza sobre a verdade das coisas", pois tudo está em movimento, fluxo. A conclusão de Aquino é de que "a alma conhece os corpos por meio do intelecto, por um conhecimento imaterial, universal e necessário", AQUINO, 2002, p. 500. O que fundamenta sua busca metodológica pelo caráter de certeza da verdade, pois demonstra-se que o intelecto pode conhecer as coisas exteriores ao intelecto.
} 
casa, quem causou a casa. Ele afirma que a casa se refere ao intelecto do artífice que a criou por si mesma, por necessidade, isso porque entre o intelecto do artífice e a casa há uma relação de causalidade e dependência, ou seja, o princípio da casa está no intelecto do artífice, necessariamente. Assim, conforme Aquino, "uma coisa é verdadeira, absolutamente falando, segundo a relação com o intelecto de que depende" (AQUINO, 2001, p. 359), o que leva a conclusão de que "uma casa é verdadeira quando se assemelha à forma que está na mente do artífice" (AQUINO, 2001, p. 359). O princípio de ordenação da casa está no intelecto de seu causador, de modo que a verdade da casa será a verificação, comparação entre o princípio de ordenação da casa e a coisa, a casa, ainda que tal comparação seja mediada pela imagem abstraída da coisa (casa).

Analisando o exemplo, podemos perguntar: a casa que está aí presente, diante de um observador, não será verdadeira, caso não esteja em total concordância com a forma inicialmente pretendida pelo arquiteto? Para saber se a casa é verdadeira, será necessária a presença do arquiteto para assim a comprovar. A concordância com a forma, com a ideia, presente em sua mente; a casa será verdadeira somente se pudermos contar com a presença e/ ou o testemunho do arquiteto. Mas, se por acaso, durante a construção de uma casa, o construtor identificar uma falha no projeto do arquiteto, numa parede ou no cálculo da altura ou inclinação de uma das águas do telhado? Em nossa legislação, os órgãos fiscalizadores responsáveis por cotejar a coisa e o projeto - que seria a imagem material, e fiel, da imagem, isto é, da forma na mente do arquiteto - não medem cada centímetro da casa, de suas paredes e lajes, e talvez nem seja o caso de fazê-lo. Verificam, sim, o número de cômodos, as condições de habitação, a legalidade dos documentos de posse do terreno, as regras gerais de construção relativas a cada munícipio, estabelecidas de acordo com interesses políticos e econômicos locais, verificam a área total construída, com vista grossa, para a taxação do imposto predial. E ainda assim, apesar das diferenças que sempre irão existir, por motivos diversos, entre o projeto do arquiteto e a casa, constatadas caso o fiscal seja um perfeito seguidor das leis em vigor, apesar de tudo isso, estão, na casa, os moradores, abrigados, unidos e aquecidos junto à mesa, no inverno, enquanto o vento toca o lado de fora da janela da casa e o orvalho 
molha as flores do jardim. O que é a verdade em si mesma, então? Para os moradores, a casa é real.

Assim compreendida a noção de verdade, esta será submetida a uma relação de causalidade, entre intelecto e coisa, relação operada pelo intelecto. Passando do intelecto divino para o intelecto humano, chegando à coisa, à casa, a razão de verdadeiro irá concordar ou não, adequar-se ou não, conformar-se ou não com a coisa. Se houver adequação entre intelecto e coisa, verdadeira será a casa, e somente assim. A verdade está no intelecto divino, passa para o intelecto humano e conforma-se pela imagem abstraída da coisa. O intelecto, ou o sujeito, ou a consciência de, possui a verdade, pois possui igualmente a ideia verdadeira das coisas. Pergunte-se: como apareceu a verdade ou a razão de verdade para a consciência? Apareceu no ato do intelecto, no inteligir. Quem garantiu a passagem da verdade primeira do intelecto divino para o intelecto humano, do intelecto humano para a coisa? Deus, o intelecto divino. Essa fundamentação está garantida, porque "toda apreensão do intelecto [humano] tem a Deus por causa" (AQUINO, 2001, p. 367), e ainda porque "não somente a verdade está nele, mas que Ele próprio é a suprema e primeira verdade" (AQUINO, 2001, p. 366), e "a verdade do intelecto divino é a única, e por ela todas as coisas são denominadas verdadeiras" (AQUINO, 2001, p. 368). Donde se conclui que é apenas no intelecto divino que a verdade é eterna, o que explica não conhecermos verdades eternas em nós mesmos, por que para haver verdade eterna, essa verdade deverá estar num intelecto eterno e é só o intelecto divino que é eterno ${ }^{12}$. Eterno e imutável ${ }^{13}$.

Assim, fica demonstrada a possibilidade de a verdade passar do intelecto para a coisa, da coisa para o intelecto, segundo o encaminhamento escolástico da questão da verdade, de modo que deve haver uma referência por si das coisas às suas causas. Por necessidade, há a referência de causa e coisa, passando por si, de um a outro termo, devido ao próprio ato do conhe-

\footnotetext{
${ }^{12}$ Conforme Tomás de Aquino, "se não houvesse intelecto eterno, não haveria verdade eterna. Como, porém, somente o intelecto divino é eterno, é apenas nele que a verdade é eterna", (AQUINO, 2001, p. 370).

${ }^{13}$ Conforme Tomás de Aquino, "A verdade do intelecto divino é então imutável. A verdade, contudo, de nosso intelecto, é mutável. Não que ela própria seja o sujeito dessa mudança, mas pelo fato de que nosso intelecto passa do verdadeiro ao falso", (AQUINO, 2001, p. 372).
} 
cimento se estender para fora do intelecto, e porque o ente e o verdadeiro são convertíveis entre $\mathbf{s i}^{14}$. Com tudo isso, é possível afirmar que "a verdade está principalmente no intelecto, secundariamente nas coisas, na medida em que se referem ao intelecto como a seu princípio" (AQUINO, 2001, p. 359), como se refere necessariamente à causa.

\section{O dizer da verdade}

A conclusão do primeiro artigo é que a verdade está principalmente no intelecto, secundariamente nas coisas, isto é, no real. Já que a verdade está principalmente no intelecto, é a partir dele que a verdade deverá ser analisada cuidadosamente. Essa parece ser a indicação necessária contida na pergunta do segundo artigo: a verdade está no intelecto que compõe e divide? Sim, é a resposta. O intelecto que compõe e divide significa: o intelecto que julga "construindo uma proposição na qual um atributo é afirmado de um sujeito (composição) ou negado (divisão)"15 (AQUINO, 2001, p. 360). Assim, verdade é um juízo ${ }^{16}$, o estágio final da intelecção, uma proposição que afirma ou nega algo de uma substância, do sujeito de um enunciado. Conhecer a verdade, portanto, é conhecer a "conformidade do intelecto e da coisa", conformitatem intellectus et rei (AQUINO, 2001, p. 361). Portanto, segundo suas palavras "não é pelo fato de [o intelecto] conhecer a essência da coisa que ele apreende essa conformidade, mas quando julga que a coisa assim é, como é a forma que dela apreendeu; é então que começa a conhecer e a dizer o verdadeiro. E isto faz compondo e dividindo" (AQUINO, 2001, p. 361). Ou seja, a verdade está no ato do intelecto que julga. Deste modo, para conhecer a verdade é necessário que o intelecto esteja em ato de ajuizar por meio de proposições, enunciados. O dizer proposicional, portanto, é ne-

\footnotetext{
${ }^{14}$ Conforme AQUINO, 2001, p. 363.

15 Nota $b$ da edição.

${ }^{16}$ Conforme nota $d$, questão dezesseis, artigo 2, "O ato pelo qual o intelecto conhece e afirma (afirma-se inicialmente a si mesmo) o verdadeiro é o juízo. O importante é dar-se conta de que o juízo é, para todo intelecto, a intelecção acabada. O que é próprio ao ser humano evidentemente não é julgar, é que o ato de julgar requer para ele um ato de conhecimento prévio, uma intelecção imperfeita: devido à necessidade em que ele se encontra de abstrair o inteligível do sensível, ele precisa, mediante uma segunda operação, voltar ao ser que só se apresenta a ele, de início, submerso no sensível e no material. A 'proposição', ou 'enunciado', é uma construção lógica que lhe é necessária para alcançar o real e julgá-lo.”, AQUINO, 2001, p. 362.
} 
cessário ao conhecimento da verdade. Isso porque a "verdade dos enunciados não difere da verdade do intelecto. Pois, o enunciado está no intelecto e está na palavra” (AQUINO, 2001, p. 370), ou seja, está dentro e está fora do intelecto. Comprova-se, pois, ainda uma vez a passagem da verdade do intelecto para o mundo exterior, já que a palavra enquanto expressão e proposição não está mais no âmbito do intelecto, mas sim revela sua verdade. Restaria estabelecer o modo como o dizer proposicional se estrutura, tornando mais evidente como esse dizer proposicional é capaz de apresentar ou reapresentar a verdade inteligida contida no intelecto humano - sendo garantida pelo intelecto divino. Para Tomás de Aquino, o dizer se estrutura segundo os princípios da lógica clássica e da teologia, e isso é o bastante.

Ainda que seja facultado ao intelecto passivo, com sua abstração formal, conhecer realidades inteiramente abstratas, estas devem estar articuladas necessariamente com as coisas, ou melhor, com as imagens abstraídas, isto é, imagens construídas diretamente a partir dos entes, decorrentes dos sentidos. Qualquer outra realidade que não se articule, ou melhor, qualquer realidade que não seja abstraída diretamente das coisas corpóreas, não poderá jamais ser considerada verdadeira, pois que a verdade é a conformidade de coisa e intelecto. $\mathrm{O}$ caso da poesia, assim, deveria ser submetido a essa validação, a saber, a conformidade de coisa e intelecto com o concurso, é claro, do intelecto divino e sua verdade. Neste caso, devemos procurar pensar o que irá restar para a poesia!

Se, por um acaso, não nos contentarmos com as conclusões de Tomás de Aquino, restará a necessidade de explicação de algumas questões que não foram devidamente elaboradas ou explicitadas. Não ficou esclarecido, por exemplo, o que fundamenta a afirmação de que intelecto e real/coisa estão separados primordialmente? Desta indagação decorre outra: o que irá igualmente fundamentar a necessidade do intelecto abstrair a essência das coisas reais existentes fora do intelecto para que, só assim, haja uma experiência do homem com a verdade? Quem não emite juízos não será capaz de experimentar a verdade? Na medida em que o intelecto só é capaz de conhecer em função do próprio real, não estaria o real ligado ao intelecto originariamente e, por esse motivo, o intelecto já não seria desde sempre 
dependente do real para a elaboração de verdades? ${ }^{17}$ Em respondendo positivamente a esta última pergunta, não estaremos impedidos de considerar realidades inteiramente imateriais? As noções de real e intelecto estão fundamentadas numa separação ontológica, pois já são pensados, intelecto e coisa, a partir de um abismo, ou seja, são apresentados como naturezas distintas que se comunicam de uma maneira bastante estranha. O que há originariamente é a possibilidade do aparecer, tanto do real e do intelecto. Isso porque o intelecto participa do próprio real, na medida em que dele depende e igualmente é real. Restaria decidir se chamaremos de deus ${ }^{18}$ a suprema possibilidade do aparecer.

\footnotetext{
17 Ainda que o realismo tomista pressuponha a relação de intelecto e coisa para o conhecimento da verdade, como explicar a existência de anjos ou ideias verdadeiras acessíveis apenas pelo intelecto, já que "nosso intelecto não pode conhecer em ato sem voltar-se para as representações imaginárias", o que nos leva a conclusão de que nosso intelecto "não pode conhecer nada de imaterial", AQUINO, 2001, p. 516? Podemos, portanto, considerar falso "que conhecemos a própria verdade, Deus e os anjos", pois, conforme Aquino, "deve-se dizer que conhecemos as coisas incorpóreas, das quais não se tem representações imaginárias, por comparação com os corpos sensíveis, dos quais são as representações imaginárias. Assim, conhecemos a verdade considerando a coisa a respeito da qual procuramos a verdade; assim, segundo Dionísio, conhecemos a Deus como causa, por via de eminência ou por negação. Quanto às outras substâncias imateriais, só podemos conhecê-las, no estado da vida presente, por negação, ou por comparação com as coisas corporais. Em consequência, quando conhecemos algo dessas substâncias, devemos nos voltar às representações imaginárias dos corpos, embora não sejam representações imaginárias deles mesmos”, AQUINO, 2002, pp. 518-519.

18 Até o momento não discutimos a relação circular da fundamentação da verdade em deus e entre a prova da existência de deus; pois, se deus não existir, não há verdade, consequen temente. Não será possível aqui pensar a relação entre a ideia de causalidade e $A$ Existência de Deus, contida na questão 2 da Suma Teológica. A questão apresenta a existência de deus, em vista da noção de causalidade e finalidade, a relação entre causa e efeito. É a noção de causalidade e todo o seu aparato, articulada com a noção de fim, que irá sustentar a existência de deus, bem como da verdade. Aquino firma que "existem dois tipos de demonstração" para tornar visível a existência de deus: "uma pela causa, e se chama propter quid; ela parte do que é anterior de modo absoluto. Outra, pelos efeitos, e se chama quia; ela parte do que é anterior para nós. Sempre que um efeito é mais manifesto do que sua causa, recorremos a ele a fim de conhecer a causa. Ora, por qualquer efeito podemos demonstrar a existência de sua causa, se pelo menos os efeitos desta causa são mais conhecidos para nós, porque como os efeitos dependem da causa, estabelecida a existência do efeito, segue-se necessariamente a preexistência de sua causa. Por conseguinte, se a existência de Deus não é evidente para nós, pode ser demonstrada pelos efeitos por nós conhecidos", AQUINO, 2001, p. 164. Estas noções estão igualmente contidas no terceiro artigo, onde se busca a resposta para a pergunta se Deus existe? As cinco vias para a prova da existência de deus dependem diretamente das noções de causalidade e finalidade. Ele afirma ainda: "deve-se afirmar que, como a natureza age em vista de um fim determinado dirigida por um agente superior, é necessário fazer chegar até Deus, causa primeira, tudo o que a natureza faz. Do mesmo modo, tudo o que é feito por uma livre decisão é necessário fazer chegar a uma causa mais elevada, além da razão ou da vontade humana. É necessário, pois, que o que é mutável e falível chegue a um princípio imóvel e necessário por si mesmo", AQUINO, 2001, p. 169.
} 


\section{A Questão da Falsidade na Suma Teológica}

\section{Exposição da Questão da Falsidade}

Eis a síntese da questão dezessete: no primeiro artigo, Aquino irá afirmar que não há falsidade nas coisas; não estando a falsidade nas coisas, ele passa a analisar, no segundo artigo, se a falsidade está nos sentidos, o que também será negado; se a falsidade não está nas coisas nem nos sentidos, ela está no intelecto que compõe e divide, assim como a verdade, o que será analisado no terceiro artigo; aqui, já poderíamos dar a questão por encerrada, se não fosse a necessidade de reforçar e defender a tese de que a verdade e a falsidade são noções contrárias, no quarto e último artigo, demonstra de modo indireto os princípios da lógica aristotélica, e se afasta da compreensão agostiniana acerca das fábulas, o que trataremos a seguir.

A falsidade deve ser procurada no intelecto, lá onde se encontra a verdade. Verdade e falsidade são opostas e se dão no intelecto: "Nas coisas não há verdade ou falsidade, a não ser com relação ao intelecto" (AQUINO, 2001, p. 374). Do mesmo modo que a verdade só pode ser observada a partir da relação entre coisa/realidade e intelecto, o mesmo se dá em relação à falsidade. Segundo o conceito de verdade e falsidade aqui em questão, a atividade intelectiva tem a função de julgar: o juízo só poderá ser ou verdadeiro ou falso. Assim, a falsidade está na relação intelecto-coisa. A falsidade que se atribui às coisas decorre da inconformidade entre a coisa e o intelecto entre a coisa e a arte que a realiza, caso estejamos tratando de coisas artificiais. As coisas artificiais podem ser falsas de modo absoluto ou sob certo aspecto. As coisas são falsas de modo absoluto em referência ao intelecto de que depende, referindo-se a ele por si, de modo necessário. As coisas artificiais também podem ser falsas, sob certo aspecto, quando se referem por acidente a um intelecto humano, quando dele não dependem.

Como diz Aquino, verdade e falsidade se opõem no intelecto. Mas que intelecto? O intelecto humano ou o intelecto divino? Necessariamente, essa oposição entre verdade e falsidade só pode ocorrer no intelecto humano e ainda será analisado o seu caráter absoluto ou condicionado, sob certo aspecto. Como relação às coisas naturais, estas "dependem do intelecto divino como as artificiais dependem do intelecto humano!" (AQUINO, 2001, p. 
374) No caso das coisas artificiais, isto é, no caso das realidades construídas pelo homem, dependentes do intelecto humano, referindo-se por si, isto é, por necessidade ao intelecto de que são dependentes, estas realidades podem ser julgadas falsas ou verdadeiras, em função de sua conveniência ou concordância com a realização da arte de seu artífice. Isso desloca a verdade ou a falsidade de um âmbito individual, de um intelecto individual, para um âmbito epistemológico da "arte" em questão. Assim, a oposição: ou a coisa é verdadeira, ou a coisa é falsa, em relação à arte. Já no caso do intelecto divino, não há oposição entre verdadeiro e falso, posto que "nas coisas que dependem de Deus [as coisas naturais] nada podemos encontrar de falso, se as considerarmos em sua relação com o intelecto divino." (AQUINO, 2001, pp. 374-375) Portanto, pelo intelecto humano, as coisas naturais só podem ser consideradas verdadeiras ou falsas sob certo aspecto - para as coisas naturais não teremos jamais um juízo absoluto, pois é Dele que elas dependem; já as coisas artificiais podem ser consideradas verdadeiras ou falsas também sob certo aspecto ou de modo absoluto; e verdade e falsidade se opõem entre si, não cabendo uma terceira opção de juízo, ao menos de modo absoluto, para as coisas artificiais, sendo julgadas verdadeiras e falsas ao mesmo tempo.

\section{$A$ falsidade e as coisas}

Segundo o critério de concordância ou discordância com a forma da arte, a concordância/discordância de coisa e intelecto, ou melhor, coisa e princípios teórico/formais estabelecidos pelo intelecto humano, assume-se um traço de imparcialidade, visto que, o critério está na coisa em referência à arte de que depende - ainda que a arte seja um saber ou conhecimento pertencente ao intelecto humano. Assim, a verdade ou a falsidade não irá depender da percepção particular e parcial daquele que investiga a verdade. Para que esse critério cumpra de modo eficaz sua função, será preciso apenas estabelecer de forma unívoca os preceitos orientadores de cada arte. Neste caso, devemos retomar o exemplo da casa, mencionada acima. Quanto ao que foi exposto, cabe perguntar se é possível julgar a falsidade ou verdade de um prédio residencial, construído segundo os moldes da arquitetura 
contemporânea, uma maloca tupi-guarani e um castelo gótico com os mesmos critérios, critérios da arte da construção civil. Parece que cada caso está determinado por leis próprias de sua inserção social e histórica. O que gera um problema para o estabelecimento da verdade, pois ela deverá ser sempre verdade sob certo aspecto e não de modo absoluto: a cada vez, verdadeiro e falso. Esse mesmo problema pode ser transposto para toda e qualquer forma de arte - arte entendida como um fazer e realizar algo - já que a questão de Aquino é procurar dispor da verdade em todos os setores do real, sem estabelecer especificidades e distinções.

Quanto às coisas naturais, como já foi destacado, o intelecto humano só poderá ajuizar sobre a verdade ou falsidade das coisas sob certo aspecto, visto que as coisas naturais só se referem ao nosso intelecto de modo acidental. As coisas naturais só se referem de modo necessário, por si, ao intelecto divino. No modo de as coisas naturais se referirem ao intelecto humano há duas maneiras em que elas podem ser consideradas falsas: 1. as coisas podem ser falsamente representadas ou significadas; 2. as coisas podem causar uma intelecção falsa ${ }^{19}$. Na primeira situação, sendo as coisas falsamente representadas, Aquino menciona como exemplo a passagem em que Agostinho trata da questão do mútuo pertencer de verdade e falsidade e afirma "que um ator trágico é um falso Heitor" (AQUINO, 2001, p. 375). Aquino usa o exemplo de Agostinho como argumento para afirmar que não podemos ajuizar a verdade ou a falsidade acerca de coisas naturais, de modo absoluto, o que de certo forma, pode servir de justificativa para o caso de cometermos um erro de juízo, quando afirmamos a verdade ou a falsidade de algo natural. E mais: o erro resulta de uma condição que impossibilita nosso juízo de julgar coisas naturais de modo absoluto, posto que não dependem de nosso intelecto, não se referem a nosso intelecto por si.

Há na escolha de Aquino, o caso citado do ator trágico, um aspecto curioso, pois Aquino vai de encontro ao que Agostinho irá defender. Agosti-

\footnotetext{
${ }^{19}$ Neste caso, a coisa faz com que nosso intelecto tenha uma opinião falsa do que se mostra aos nossos sentidos, fazendo-nos confundir uma coisa com outra. Tomás dá o exemplo de coisas que se parecem outras, como o fel (mel) e o estanho (prata). Conforme Aquino, "E como nos é natural julgar as coisas pelo que delas vemos exteriormente, pois nosso conhecimento se origina a partir dos sentidos, e os sentidos têm como objetivo próprio e essencial os acidentes exteriores, por esta razão, o que apresenta, entre os acidentes exteriores das coisas, a semelhança de outras coisas. Assim como o fel é falso mel, e o estanho falsa prata", (AQUINO, 2001, p. 375).
} 
nho afirma exatamente o contrário do que será defendido por Tomás de Aquino na questão da falsidade. A referida passagem se encontra no seguinte título dos Solilóquios de Agostinho: Certas coisas são verdadeiras enquanto falsas. Aí está suposta a coexistência entre verdade e falsidade, e Agostinho chama a atenção para isso como algo admirável. Para demonstrar o mútuo pertencimento de verdade e falsidade, Agostinho usa como exemplo o ator Róscio, ao representar Heitor:

Róscio, por própria vontade, quando se apresentou no palco, representou o papel de falsa Hécuba, embora sendo verdadeiro homem. Mas, por essa sua vontade, manifestou-se verdadeiro ator trágico, por representar bem o papel que lhe fora atribuído. Entretanto quando representava Príamo, era falso por que se assemelhava a Príamo, mas não o era. Daí resulta algo admirável que ninguém duvida em admiti-lo. (AGOSTINHO, 1998, p. 78)

Ninguém se negaria em admitir que certas coisas são verdadeiras enquanto são falsas, pois há coisas que "se destinam a serem falsas, nem o são a seu critério, mas o são por certa necessidade de imitar" (AGOSTINHO, 1998, p. 78). Agostinho continua a questão, afirmando a indubitável e admirável verdade:

Daí resulta algo admirável que ninguém duvida em admiti-lo. // - E o que é? - O que achas senão que todas essas coisas, por um lado, são verdadeiras em alguns e, por outro lado, falsas em outros e, quanto ao ser verdadeiro, isto só é de utilidade para aqueles pelo fato de serem falsas para outros? Se tais coisas deixarem de ser falsas, de modo algum elas chegam a ser aquilo que querem ou devem ser. Pois como esse, que citei acima, seria um verdadeiro ator trágico se não quisesse ser falso Heitor, falsa Andrômaca, falso Hércules e inúmeras outras personagens? (AGOSTINHO, 1998, p. 78)

A resposta necessária: não poderia ser verdadeiro ator se quisesse ser verdadeiro Heitor. E assim, a arte de representar seria o caso das coisas verdadeiras enquanto falsas, por princípio.

Ao contrário, se interpretarmos o caso da representação teatral a partir de Tomás de Aquino, seríamos obrigados a tomar a arte de representar como falsa, sob certo aspecto, sob o aspecto de o personagem Heitor não ser o Heitor mesmo. Isto se considerarmos o que se está representando como uma coisa ou realidade natural - o homem Heitor. A arte de representar poderia também ser verdadeira somente sob certo aspecto, caso se analise a representação como uma coisa artificial: a representação seria verdadeira em 
concordância com a forma da arte de representar. Apesar disso, Aquino não segue essa linha de interpretação, apesar de afirmar, inversamente, podermos "dizer de qualquer coisa que é verdadeira segundo o que lhe convém" (AQUINO, 2001, p. 375). Tomás de Aquino contextualiza o caso da representação teatral no âmbito da falsidade, sob a perspectiva das coisas naturais. Em sua decisão interpretativa ${ }^{20}$, fica em destaque o aspecto falso da representação teatral quanto ao que nela, na coisa, "não se encontra" (AQUINO, 2001, p. 375). A partir de tal perspectiva, o ator, melhor, em sua representação, o representado (Heitor ou qualquer outro homem) será sempre falso, pois a representação estará sendo avaliada apenas por mostrar a semelhança do representado e jamais ele mesmo, ainda que a representação convença e seja boa sob o ponto de vista da forma da arte. É curioso por que Aquino menciona a arte de representar como exemplo das coisas naturais, porque aponta tal arte como o caso exemplar do falso, a arte de representar como exemplo do falso segundo as coisas naturais. Por que afirmar a arte de representar como exemplo do falso nas coisas naturais, se nossa relação com ela, com a representação teatral, não está rigorosamente no âmbito das coisas naturais, mas sim artificiais?

Está pressuposto nessa compreensão o entendimento da representação teatral como imitação (mímesis). O ator trágico imita/representa o Heitor (verdadeiro), mas em seu representar, ainda que convença e apareça como verdadeiro ator trágico, o que produz ou reproduz, no caso Heitor,

\footnotetext{
${ }^{20}$ Para confirmar o tom interpretativo de Agostinho, consultar ainda o Capítulo XI dos Solilóquios, Verdade das Ciências. Fábula. Gramática, onde Agostinho afirma o caráter de aprendizado da verdade por meio das fábulas: "R. [...] Mas ninguém pode dizer-se que não sabe aquilo que aprendeu e conserva na memória; por outro lado, ninguém sabe coisa falsa. Portanto, toda ciência é verdadeira. // A. Não vejo neste breve raciocínio algo com que concordar temerariamente. Entretanto, é de meu interesse o fato de que, por este breve raciocínio não venham parecer a alguém que também aquelas fábulas sejam verdadeiras, pois também as aprendemos e as guardamos na memória. // R. Por acaso nosso professor não queria que acreditássemos nas coisas que ele ensinava, mas sim que as aprendêssemos? // A. Ele insistia muito para que as aprendêssemos. // R. Acaso pediu alguma vez que acreditássemos que Dédalo voou? // A. Isso nunca. Mas se não aprendêssemos de cor uma fábula, ele dava palmadas, fazendo com que nossas mãos ficassem de tal modo, que mal podíamos segurar alguma coisa. // R. Portanto, negas que é verdade que esta fábula existe e que, por ela, cor reu a fama de Dédalo? // A. Não nego que isso seja verdade. // R. Portanto, não negas que, ao aprender tais coisas, aprendeu uma coisa verdadeira. Se fosse verdade que Dédalo tivesse voado e se as crianças, no entanto, aprendessem este fato e o transmitissem como fábula imaginária, eles estariam conservando e admitindo como falso aquilo que seria um fato verdadeiro. Por essa razão resultava aquilo de que nos admirávamos antes: do vôo de Dédalo não poderia resultar uma verdadeira fábula, se não fosse falso que Dédalo tivesse voado." AGOSTINHO, 1998, p. 81.
} 
será sempre falso. Portanto, o falso que Aquino põe em destaque não é a representação teatral, mas sim o caráter falso daquilo que no representado não se encontra, e que jamais poderia ser encontrado: o ator, isto é, o Heitor mesmo. Ainda assim, ele destaca apenas o aspecto falso da arte de representar, pelo critério da imitação do real. A apropriação de Aquino soa problemática, porque na arte de representar, o representar mesmo não está na relação de falso e verdadeiro. Por extensão, para o nosso caso, a pergunta que nos cabe é: a poética (poietike) também deverá ser tomada como representação do real, do verdadeiro? Para o caso da poesia, o que ela realiza? Imitação do real? A poesia realiza algo de real?

Daí o problema de Aquino: como será a distinção precisa entre o que é realidade estritamente natural e realidade estritamente humana ou artificial, para a aplicação adequada dos critérios de verdade e falsidade do pensamento medieval acerca da arte? Onde está o limite das coisas naturais e das coisas humanas? Há esse limite? Não seria o homem também parte da natureza, da physis grega? Por extensão, se o homem é uma realidade natural e se este seu fazer, a mímesis teatral, é considerada uma atividade natural, quais coisas seriam humanas, isto é, artificiais? E seguindo essa interpretação, sendo a mímesis uma realidade natural, seria possível dela ajuizar de modo adequado, sem a consecução de Deus? Ou bem ela, a mímesis, é natural e dela não podemos ajuizar de modo absoluto, ou, ela é uma coisa artificial e a ajuizamos de acordo com a forma da arte. Na verdade, nos parece que deus nada tem que ver com o teatro - o menos o deus de Aquino.

Em sua fala imediatamente anterior à possibilidade do homem julgar as coisas naturais sob certo aspecto, é curioso observar que Aquino destaca a virtude do homem que segue a verdade da vida, subordinando-se "à ordem do intelecto divino: segundo a palavra de João: 'Aquele que age segundo a verdade vem à luz"' (AQUINO, 2001, p. 375). O que fica evidente aí é que a instância divina é essencial para o ajuizamento do verdadeiro e do falso, tanto nas coisas naturais como artificiais, pois "tudo o que acontece nas coisas provém da ordenação do intelecto divino" (AQUINO, 2001, p. 375). Em sua resposta geral ao primeiro artigo da questão dezessete, Aquino ressalta a fundamentação divina da verdade: "qualquer coisa, enquanto é, imita Deus. 
Logo, todas as coisas são verdadeiras, sem falsidade. Assim, nenhuma coisa é falsa" (AQUINO, 2001, p. 374). Sendo assim, em Deus, tudo é verdadeiro.

Tomás de Aquino concentra suas afirmações na defesa da tese de que não há falsidade nas coisas. Em última instância, estando a falsidade no intelecto humano ${ }^{21}$, o falso é atribuído às coisas sempre sob certo aspecto ou por acidente. Segundo Aquino, as coisas "não enganam por si", mas "dão ocasião à falsidade pelo fato de parecerem semelhantes a coisas que não têm existência" (AQUINO, 2001, p. 376). Deste modo a falsidade não está na coisa, mas a coisa dá oportunidade ao engano e a falsidade.

Em sua resposta à última objeção, fundamentada na visão agostiniana de que algumas coisas são e não são ao mesmo tempo, conforme se argumentava em sentido contrário, Aquino rejeita a tese de que "Todo corpo é verdadeiro corpo e falsa unidade" (AQUINO, 2001, p. 374). Responde Aquino:

uma semelhança ou uma representação deficiente não induz a razão de falsidade exceto quando dá oportunidade a uma opinião falsa. Portanto, não se diz que haja falsidade onde existe uma semelhança, mas apenas onde esta semelhança é capaz de criar uma opinião falsa, não em alguns mas na maioria. (AQUINO, 2001, p. 376)

Em sua resposta, Aquino não diz explicitamente que Agostinho está errado, mas deixa subentendido que a afirmação não diz a verdade. No caso do corpo humano, ele é sim, verdadeiro corpo e verdadeira unidade para Aquino $^{22}$. A falsa unidade percebida por Agostinho seria o resultado da oportunidade a uma opinião falsa própria ao corpo humano, unindo corpo e alma. Assim, em si mesmo, o corpo, sendo verdadeiro corpo, não guarda em si a falsidade de parecer a unidade de corpo e alma. Corpo e alma representam verdadeira unidade. Portanto, afasta a possibilidade de a falsidade estar em todas as coisas.

\footnotetext{
${ }^{21}$ Conforme Aquino, "não é com referência ao intelecto divino que as coisas são denominadas falsas [...] é com referência a nosso intelecto, que elas [as coisas] são falsas sob certo aspecto", AQUINO, 2001, p. 376.

${ }^{22}$ Ver questão 76, Parte I, Volume II. Tomás de Aquino irá defender a unidade do corpo humano com a alma intelectiva ou intelecto.
} 


\section{Falso ou verdadeiro}

Vale ainda destacar do primeiro artigo acerca da questão da falsidade, a primeira objeção, bem como a resposta que Aquino lhe dá. A objeção é iniciada com a afirmação de que não há falsidade nas coisas: "Se o verdadeiro é o que é, deve-se concluir que o falso não se encontra em lugar nenhum, apesar de todas as objeções" (AQUINO, 2001, p. 374), isto porque $o$ que é deveria ser considerado sempre verdadeiro, enquanto o que não é, considerado falso. A afirmação de Agostinho é destacada dos Solilóquios, Livro II, Capítulo VIII, De onde o verdadeiro ou o falso, parágrafo 15. Nos Solilóquios, vemos a dúvida de Agostinho a respeito da contradição entre o verdadeiro e o falso. Podemos adiantar que Agostinho não está tão certo quanto Aquino, a propósito da oposição entre verdadeiro e falso. Tal certeza ficará evidente na resposta às objeções. Ainda que o contexto da fala de Agostinho revele suas indecisões entre a oposição de verdade e falsidade, a objeção inicial do artigo é apresentada como se Agostinho a tomasse como resolvida.

Tomás de Aquino põe verdade e falsidade como alternativas opostas desde o início de sua resposta: "o verdadeiro e o falso se opõem” (AQUINO, 2001, p. 374). Agostinho não está interessado em apresentar de modo decisivo a questão. No mesmo capítulo em que lemos a fala de Agostinho, supostamente defendendo a inexistência da falsidade, lemos também a afirmação de que não há verdade: "todas as coisas são falsas, pois todas as coisas, como foi dito acima, de algum modo são semelhantes e dessemelhantes entre si” (AGOSTINHO 1998, p. 75). É importante ressaltar que Agostinho está discutindo a questão, ao passo que Aquino já a apresenta de modo decidido. Para Agostinho, o que importa é se as coisas são falsas "à medida que diferem das coisas verdadeiras" (AGOSTINHO 1998, p. 74), devido à semelhança ou à dessemelhança com relação à verdade..$^{23}$

\footnotetext{
${ }^{23} \mathrm{O}$ que se quer destacar com esses apontamentos é justamente o descompasso entre o encadeamento da discussão realizada nos Solilóquios de Agostinho e a interpretação de Tomás de Aquino. Sendo assim, podemos acompanhar em Agostinho o seguinte encadeamento: 1. no Capítulo VIII - De onde o verdadeiro ou o falso, Agostinho apresenta a oposição entre verdade e falsidade, destacando de tal oposição que ou todas as coisas são verdadeiras ou todas as coisas são falsas; 2. no Capítulo IX - Que é falso, enganador e mentiroso, Agostinho chega à conclusão de que mentir é diferente de enganar, donde "nem todo aquele que mente deseja enganar. As representações teatrais com mímicas, as comédias e muitos poemas são repletos de ficções, criadas mais por razão de lazer que por vontade de enga-
} 
Em sua resposta à referida objeção, Aquino irá discordar da afirmação atribuída a Agostinho. A afirmação de Agostinho só aparentemente defende que não há falsidade em lugar algum. Para Aquino, ela funciona como pretexto para o desfecho que deseja arquitetar. Aquino segue uma linha de interpretação que defende a verdade das coisas que são e a falsidade das coisas que não são. Somente as coisas que são o que são podem ser consideradas verdadeiras. Aquino não pretende discutir a possibilidade das coisas que são verdadeiras e falsas a um só tempo. Ele defende a posição que entende a relação entre verdade e falsidade como âmbitos contrários. Conforme sua resposta à objeção,

deve-se dizer que a coisa referida ao intelecto, segundo o que ela é, é considerada verdadeira e falsa segundo o que não é. Por isso, Agostinho nota que um verdadeiro ator trágico é um falso Heitor. Assim como um certo não-ser se encontra nas coisas que existem, assim também nelas existe certa falsidade. (AQUINO, 2001, p. 376)

Eis a resposta em que Aquino utiliza o exemplo do ator trágico, exemplo que será retomado no quarto artigo da questão dezessete. Aquino considera a coisa verdadeira "segundo o que ela é" e a mesma coisa "falsa segundo o que não é”. No exemplo, o ator será considerado verdadeiro, e também será falso Heitor. Ele conclui que pode haver certa falsidade (nãoser) nas coisas que existem (verdadeiras). Na última frase de sua resposta, Aquino parece querer dizer que, ainda que seja verdadeiro ator, encontrando-se nele, no ator, no ato de representar, um certo não-ser (Heitor), haverá nele, no verdadeiro ator, certa falsidade. Aquino não discute as coisas que são verdadeiras e falsas ao mesmo tempo. Também não nega a possibilidade de as coisas serem verdadeiras e falsas ao mesmo tempo, nem menciona a tese agostiniana das coisas verdadeiras enquanto falsas, que é o contexto de compreensão do caso do ator trágico. Se Aquino encerrasse sua menção ao ator trágico em sua resposta geral para artigo, tratada anteriormente, não haveria nenhum comprometimento na resposta com relação à tese agostiniana. Não poderíamos afirmar sua concordância ou discordância, decisivamente, em relação ao encaminhamento que Agostinho oferece para

nar”, AGOSTINHO 1998, p. 76; 3. no Capítulo X - Certas coisas são verdadeiras enquanto falsas, irá concluir que "todas essas coisas, por um lado, são verdadeiras em alguns e, por outro lado, falsas em, outros", AGOSTINHO 1998, p. 78. Aquino rechaça essa possibilidade interpretativa, simplesmente desconsiderando a discussão. 
a questão da ficção. Aquino não afirma nem a verdade nem a falsidade da ficção, da poética, apesar de decretar a falsidade do ator, melhor, do Heitor, e simplesmente ignorar a discussão que é desenvolvida por Agostinho a respeito das coisas que são verdadeiras enquanto são falsas, em seus Solilóquios. A questão da verdade ou falsidade do dizer poético jamais seria uma questão para Aquino. No entanto, Agostinho reconhece o caráter de ensinamento da ficção, bem como sua possibilidade de conduzir ao conhecimento da verdade, ainda que seja considerada falsa. ${ }^{24}$

Aquino menciona o exemplo do ator trágico em sua resposta geral ao artigo primeiro, em sua resposta à primeira objeção do mesmo artigo e ainda menciona uma vez mais tal exemplo no quarto artigo da questão da falsidade. Neste último, temos a seguinte pergunta guia: $O$ verdadeiro e $o$ falso são contrários? Aquino retoma o exemplo do ator trágico na segunda objeção. As objeções do artigo dialogam com a hipótese de o verdadeiro e falso não serem contrários. Segundo o que consta na objeção, "um dos contrários não está no outro. Ora, o falso está no verdadeiro, uma vez que, segundo Agostinho, 'um ator trágico não seria um falso Heitor, se não fosse um verdadeiro ator trágico'. Logo, o verdadeiro e o falso não são contrários.” (AQUINO, 2001, p. 382). Aquino irá articular a sua argumentação para demonstrar que uma coisa não pode ser falsa e verdadeira ao mesmo tempo, seguindo um dos princípios básicos da lógica aristotélica, a não-contradição. Tal argumentação se contrapõe claramente à concepção agostiniana da verdade acerca do ator trágico. A rigor, para Aquino, o ator não seria considerado verdadeiro nem mesmo sob certo aspecto. Tal consideração seria um erro. Isso parece estar evidente em sua resposta à objeção no quarto artigo, onde se coloca contrário ao que Agostinho defende nos Solilóquios, Li-

\footnotetext{
24 Conforme Agostinho, "R. Por acaso nosso professor não queria que acreditássemos nas coisas que ele ensinava, mas sim que as aprendêssemos? // A. Ele insistia muito para que as aprendêssemos. // R. Acaso pediu alguma vez que acreditássemos que Dédalo voou? // A. Isso nunca. Mas se não aprendêssemos de cor uma fábula, ele dava palmadas, fazendo com que nossas mãos ficassem de tal modo, que mal podíamos segurar alguma coisa. // R. Portanto, negas que é verdade que esta fábula existe e que, por ela, correu a fama de Dédalo? // A. Não nego que isso seja verdade. // R. Portanto, não negas que, ao aprender tais coisas, aprendeu uma coisa verdadeira. Se fosse verdade que Dédalo tivesse voado e se as crianças, no entanto, aprendessem este fato e o transmitissem como fábula imaginária, eles estariam conservando e admitindo como falso aquilo que seria um fato verdadeiro. Por essa razão resultava aquilo de que nos admirávamos antes: do vôo de Dédalo não poderia resultar uma verdadeira fábula, se não fosse falso que Dédalo tivesse voado." AGOSTINHO, 1998, p. 81 .
} 
vro II, Capítulo X, Quaedam vera qua falsa sunt, Certas coisas são verdadeiras enquanto falsas.

Vejamos o que Aquino diz com mais atenção: "Tragoedus non esset falsus Hector, si non esset verus tragoedus" (AQUINO, 2001, p. 382), ou "um ator trágico não seria um falso Heitor, se não fosse um verdadeiro ator trágico." (AQUINO, 2001, p. 382, grifo meu) Se observarmos com atenção, nesta passagem Aquino inverte/converte os termos da sentença, o que acaba criando um outro contexto de interpretação para a fala de Agostinho. Ao invés de colocar em questão a verdade da arte de representar, enfatizando a verdade do ator trágico, o que aparece em questão na fala do aquinate é o ser falso, como se o desejo do ator fosse alcançar a falsidade da representação de Heitor, para assim se tornar verdadeiro ator. Já no primeiro artigo de sua questão 17, a frase aparece com outra ordem: "tragoedus est falsus Hector" (AQUINO, 2001, p. 375), um ator trágico é um falso Heitor, e "verus tragoedus est falsus Hector"' (AQUINO, 2001, p. 376), um verdadeiro ator trágico é um falso Heitor. Estaríamos fazendo tempestade em copo d'água, apontando a inversão dos termos como algo problemático? Ou tal inversão de fato corrompe a ideia?

Na obra de Agostinho, como aparece a frase em questão? Em seus Solilóquios, Agostinho elabora a tese de que para ser verdadeiro ator trágico, este será falso Heitor, não por escolha mais por foça da própria atividade cênica, porque, como afirma Agostinho, "uma coisa é querer ser falso e outra coisa não poder ser verdadeiro" (AGOSTINHO 1998, p. 78). Claro que para Agostinho a questão da falsidade aí também é associada à noção de imitação (mímesis), mas ao menos para ele está em questão a verdade da atividade cênica. Diz ele: "verus tragoedus esset, si nollet esse falsus Hector" (AGOSTINHO, [S.D.] $)^{25}$, seria um verdadeiro ator trágico se não quisesse ser falso Heitor? (AGOSTINHO, 1998, p. 78) A frase aparece numa pergunta, ainda que esteja articulada com a sua retórica e sua argumentação. A leitura descontextualizada da passagem parece dar a entender que o ator deseja, isto é, ele quer ser falso. Porém, a questão é meramente lógica: no

${ }^{25}$ Conforme Livro II, Capítulo X, 18. AGOSTINHO. [S.D] Soliloquiorum libri duo. Disponível em: $<$ http://www.augustinus.it/latino/soliloqui/index2.htm>. Acesso: 19 jun. 2019. A frase completa em Latim: "Quo pacto enim iste quem commemoravi, verus tragoedus esset, si nollet esse falsus Hector, falsa Andromache, falsus Hercules, et alia innumera?". 
interior da discussão dos Solilóquios, o que se quer afirmar é que ele não quer ser o Heitor mesmo, verdadeiro; para o ator, ser o Heitor não é a questão; a questão para o ator é ser ator e representar bem o papel. O problema de Tomás de Aquino é tratar a representação teatral nos termos de verdade ou falsidade.

Segundo o que se diz nos Solilóquios, a questão da verdade recai sobre a ação do ator, ainda que sendo falso Heitor. A inversão dos termos da sentença parece se decidir pela interpretação do querer ser falso, o que, a rigor não cabe nem na compreensão agostiniana, posto que não se trata de questão de escolha, como foi destacado acima segundo suas próprias palavras. A questão é o ser verdadeiro ator. Não ser $o$ Heitor é condição sine qua nom para que o ator alcance a verdade de sua atividade. Vale lembrar, a atividade do ator é representar cenicamente alguém, por acaso, neste caso, o Heitor e fazer com que sua representação convença seu público, não de que ele, o ator em cena, é Heitor, mas sim que há qualidade/verdade em sua representação. Agostinho reconhece o estar na verdade próprio do ator, pois sua analise parte da atividade da representação/interpretação, ao contrário de Tomás de Aquino, que avalia a verdade, partindo da posição da manifestação do Heitor, como referência da imitação/representação. Vale dizer uma vez mais que o ator não deseja ser falso Heitor, mas sim ser verdadeiro ator. Ele deseja desempenhar, com a maior verdade possível, as características físicas e mais ainda aspectos do caráter de quem ele representa.

A condição de ser falso Heitor, ainda que Tomás de Aquino não a tenha colocado em questão e não a tenha analisado, deixa bastante claro de onde o caráter falso é pensado: o falso Heitor é pensado numa relação de cópia ou imitação. Existe o Heitor original e sua imitação/representação. Não seria possível pôr em dúvida a possibilidade dessa referência, pois ela é possível e tem sua razão de ser. No entanto, devemos nos interrogar se essa relação cabe na questão da verdade do ser ator. Ao imitar cenicamente Heitor, o ator não deseja mentir nem enganar; ele mesmo não acredita ser Heitor, o que seria um caso psiquiátrico e médico, do mesmo modo não deseja se passar por ele, o que seria caso de estelionato e polícia. Para o ator, a encenação se estabelece com outra relação entre ele e o real. Ainda que não seja para nós uma questão, pelo menos diretamente, talvez, o empenho do ator e o 
personagem que representa seja melhor explicado através da compreensão do $j o g o^{26}$, ou, segundo a teoria da literatura ${ }^{27}$, ou alguma teoria do teatro ${ }^{28}$.

Fato é que, a concepção de verdade em Agostinho difere da concepção de Tomás de Aquino. Em ambos, não se coloca em questão a fundamentação divina da verdade. Em Agostinho tal fundamentação aparece como artigo de fé; em Tomás, a verdade passa a figurar com explicação mais racional, assentando a verdade no intelecto divino. Ambos aceitam também que o princípio que ajuíza a verdade e a falsidade decorre da comparação entre dois entes: um verdadeiro e outro falso. Diferem entre si, especialmente no ponto em que Agostinho aceita a contradição de certas coisas serem verdadeiras e falsas, como é o caso da fábula. Na fala de Aquino, está pressuposta a concepção de arte poética como mímesis, ou seja, como imitação do real, das coisas. Ainda que a concepção de arte em Tomás de Aquino não seja exatamente a imitação platônica, de qualquer modo, a arte trágica aí é enten-

${ }^{26}$ Conforme o conceito de jogo em Gadamer, "Mesmo o espetáculo teatral continua sendo jogo, isto é, tem a estrutura do jogo estrutura de ser um mundo fechado em si mesmo", GADAMER, Hans-Georg. Verdade e método. Volume I. Petrópolis: Editora Vozes, 2011, p. 164. Gadamer ainda diz: "O jogo, ele mesmo, é uma transformação tal que a identidade daquele que joga não continua existindo para ninguém. [...] Os jogadores (ou poetas) não existem mais, existe apenas o que é jogado por eles", p. 167. E ainda: "O que não existe mais é, sobretudo, o mundo onde vivemos, que é o nosso próprio mundo. Transformação em configuração não é simplesmente transferência para um outro mundo. Certamente que é outro mundo, fechado em si, no qual o jogo joga. Mas, na medida em que é configuração, encontrou sua medida em si mesmo e não se mede com nada que esteja fora de si mesmo. É assim que a ação de um espetáculo - e nisso se assemelha totalmente à ação cúltica - está aí de modo absoluto como algo que repousa em si mesmo. Não admite mais nenhuma comparação com a realidade como se esta fosse o padrão secreto de toda semelhança figurativa. É içada acima de toda comparação desse gênero - e com isso acima da questão de saber se tudo é real -, porque por ela está falando uma verdade superior”, p. 167. Acompanhar também o conceito de apropriação/aplicação em Paul Ricoeur, descrito na dissertação $O$ conceito de apropriação como questão fundamental do projeto hermenêutico de Paul Ricoer.

${ }^{27}$ Conforme Umberto Eco, "A norma básica para se lidar com uma obra de ficção é a seguinte: o leitor precisa aceitar tacitamente um acordo ficcional que Coleridge chamou de 'suspensão da descrença'. O leitor tem de saber que o que está sendo narrado é uma história imaginária, mas nem por isso deve pensar que o escritor está contando mentiras. De acordo com John Searle, o autor simplesmente finge dizer a verdade. Aceitando o acordo ficcional e fingimos que o que é narrado de fato aconteceu", ECO, Umberto. Seis passeios pelos bosques da ficção. São Paulo: Companhia das Letras, 1994, p. 81.

${ }^{28}$ Conforme Constantin Stanislavski, em A preparação do ator, no capítulo Fé e sentimento da verdade, "na vida comum, verdade é aquilo que existe realmente, aquilo que uma pessoa realmente sabe. Ao passo que, em cena, ela consiste em algo que não tem existência de fato, mas poderia acontecer", STANISLAVISKI, Constantin. A preparação do ator. Rio de Janeiro: Civilização Brasileira, 1999, p. 168. Afirma ainda que há dois tipos de verdade em cena: 1. "o que é criado automaticamente e no plano dos fatos reais", o palco, a presença física do ator etc.; 2. "há o tipo cênico, que é igualmente verdadeiro, mas que tem origem no plano da ficção imaginativa e artística", p. 168. Ele destaca também que " $A$ verdade em cena é tudo aquilo em que podemos crer com sinceridade, tanto em nós mesmos como em nossos colegas [de cena]", p. 169. Acrescente-se que "em cena tudo deve ser real na vida imaginária do ator", p. 195. 
dida como imitação do real. Assim, a arte trágica é compreendida como dependente do real. Aí, não é posta em questão a força criadora da poética, autônoma, que se sustenta a partir de si mesma. ${ }^{29}$

\section{Falsidade e o intelecto humano}

No segundo artigo da questão dezessete, pretende-se responder à pergunta se a falsidade está nos sentidos. Se a verdade está no intelecto, conforme conclusão a que se chegou durante a questão dezesseis, não poderá estar a falsidade nos sentidos, porque "os sentidos apreendem as coisas tal como elas são" (AQUINO, 2001, p. 377). Os sentidos só poderiam ser considerados falsos se as coisas fossem apreendidas "diferentemente do que são" (AQUINO, 2001, p. 377), o que não é o caso, pois quando se trata dos “sensíveis próprios [aos sentidos], os sentidos não têm falso conhecimento, a não ser por acidente e raras vezes; porque isso provém de uma má disposição do órgão" (AQUINO, 2001, pp. 377-378).

Parece que os sentidos imprimem as impressões no intelecto tal como as recebe; e a falsidade, conforme Aristóteles, é própria à imaginação: "A falsidade não é própria dos sentidos, mas da imaginação" (AQUINO, 2001, p. 376); e ainda, tal como a verdade, a falsidade está nas coisas complexas, propriamente na atividade de compor e dividir do intelecto, e não nas realidades simples. Pois, "nas realidades incomplexas não há nem verdade nem falso, apenas nas realidades complexas" (AQUINO, 2001, p. 377). Daí, tomando como simples as realidades que são complexas - como o caso da representação teatral -, podemos ratificar Agostinho, quando diz que somos enganados pela sedução da semelhança (AGOSTINHO, pp. 6871). Ainda uma vez, perguntemos: será que cabe à representação teatral uma análise como se esta fosse uma realidade simples, ou seja, natural? Ele, Tomás de Aquino, afirma no artigo que nos enganamos apenas quanto à coisa percebida (quanto à composição no intelecto), e não quanto ao fato de sentir mesmo. Já que o sentido nunca se engana, a falsidade provém da imaginação. Segundo Aquino, a falsidade é atribuída à imaginação "porque repre-

\footnotetext{
${ }^{29}$ Ver Caminho, poética acontecimento em GALERA, F. 2013. Caminho, poética, acontecimento. Rio de Janeiro: Tempo Brasileiro. E também os ensaios do livro Convite ao pensar, em CASTRO, M. A. (Org.). 2014. Convite ao pensar. Rio de Janeiro: Tempo Brasileiro.
} 
senta a semelhança da coisa, mesmo ausente, de modo que se alguém considera a semelhança como a própria coisa, dessa apreensão provém a falsidade" (AQUINO, 2001, p. 378) ${ }^{30}$. Mas, a rigor, o problema não é a imaginação, mas sim tomar a imagem que dela se forma como a própria coisa. Com isso, nos é permitido afirmar que a falsidade está presente no intelecto que compõe e divide, isto é, o intelecto que julga e elabora sentenças e enunciados, proposições. Deste modo, a verdade e a falsidade estão no intelecto, não por alguma imperfeição da criação divina ${ }^{31}$, mas por uma falha na elaboração do juízo, o que é de inteira responsabilidade do homem.

No terceiro artigo, Aquino irá defender que a falsidade está no intelecto, podendo se apresentar de duas maneiras. $\mathrm{O}$ intelecto pode atribuir "a definição de uma coisa a outra" (AQUINO, 2001, p. 380), como por exemplo se atribuíssemos ao homem a definição do círculo ou da imortalidade. Neste caso, retomando a questão do ator trágico, não estaríamos atribuindo ao ator uma definição de uma outra coisa, no caso, a definição de homemHeitor? A segunda maneira diz respeito ao intelecto compor "partes de uma definição inconciliáveis" (AQUINO, 2001, p. 380), como por exemplo uma suposta definição de animal racional quadrúpede. Não havendo a existência de um animal racional (até o momento, o homem) que seja quadrúpede, a definição seria falsa, por buscar conciliar ideias inconciliáveis. Segunda esta outra falha na composição/proposição, ou falta que ocorre no intelecto, pergunte-se: não estaríamos atribuindo ao ator e a representação uma definição imprópria e inconciliável com a própria ideia de representação teatral, ao impor à representação a verdade de ser o próprio Heitor?

Com tudo isso, teremos de concluir, necessariamente, que: o conceito de verdade e falsidade, ou seja, a teoria da correspondência/adequação/ conformidade entre coisa e intelecto, que nos facultaria dizer a verdade ou a falsidade de algo, de alguma coisa, não se sustenta por si em sua teoria, mas necessita de fundamentação numa instância superior e além de nossos limi-

\footnotetext{
${ }^{30}$ Conforme ainda nota $d$ da edição, "Se a imaginação possui a má reputação de ser causa de erro, não é que ela se engane a si mesma, ou que nos engane conhecendo a imagem que constrói - a partir das percepções -; é que a imagem pode ser tomada pela realidade, o que ela não é", p. 378.

${ }^{31} \mathrm{O}$ problema não seria o intelecto, pois este "não se engana quanto à essência da coisa [...]", mas "quando compõe ou divide, pode-se enganar, atribuindo à coisa de que conhece a essência algo que dela não se segue, ou mesmo que lhe é oposto", AQUINO, 2001, pp. 379-380.
} 
tes cognoscitivos. Tal instância é afirmada na tradição escolástica como deus. A rigor, tudo o que foi desenvolvido na questão dezessete trata do mesmo conteúdo presente na conceituação da verdade, desenvolvida na questão dezesseis. Verdade e falsidade aqui foram tratadas como faces do mesmo: "adaequatio rei et intellectus" (AQUINO, 2001, p. 361). Portanto, toda verdade tem por causa Deus: "toda apreensão do intelecto tem a Deus por causa, de modo que tudo o que há de verdade em minha proposição [...] tem totalmente a Deus por causa" (AQUINO, 2001, p. 367). Assim, o intelecto humano é desprovido de autonomia para alcançar a verdade ou falsidade. Isso, especialmente, porque estamos falando da verdade enquanto está no intelecto humano que compõe e divide. Para o caso do intelecto divino, neste não há composição ou divisão, ou seja, não há necessidade de enunciados que mostrem a verdade. Ainda que deus conheça todos os enunciados possíveis:

Ele conhece as coisas materiais de modo imaterial e as coisas compostas de modo simples; assim conhece os enunciados, não à maneira dos enunciados, como se tivesse em seu intelecto a composição ou a divisão dos enunciados, mas conhece cada coisa por um simples conhecimento, por ele conhecendo a essência de cada coisa. (AQUINO, 2001, p. 345)

E assim, somente no caminho da ordenação do intelecto divino será conhecida a verdade.

\section{Considerações Finais}

Até aqui, buscamos encontrar o lugar da linguagem poética no âmbito da Filosofia, em especial na tradição escolástica. Com isso, conseguimos visualizar a fundamentação da relação histórica do poético com o pensamento lógico, legada por tal tradição. Segundo as concepções aqui analisada, pode-se concluir que verdade e falsidade estão fundadas numa visão teológica e a poesia/fábula está fora do âmbito da verdade.

Se não formos obrigados a aceitar a garantia da verdade a partir do deus cristão, como será garantida a verdade? Será garantida por que deus? Terá algum deus como garantia? Se não envolvermos deus algum nestas questões, como será garantida a verdade, segundo tal concepção - verdade/ falsidade como relação, adequação/inadequação, conveniência/inconveniên- 
cia, concordância/discordância? Será que a verdade realmente precisa ser garantida por algum ato, humano ou divino? A verdade precisa de nossa consecução, para que ela seja descoberta? Como ela precisa de nós? Compondo e dividindo? E qual seria a diferença essencial entre a composição e divisão que se opera na lógica e a composição e divisão que se opera na poesia, já que ambas trabalham com a imaginação do intelecto? Essas e outras questões deverão ser colocadas e respondidas, para que a concepção de verdade apresentada pela escolástica reencontre sua relação com o pensamento e com a poesia.

Qual é pois o comportamento próprio à poesia, enquanto composição imaginativa diante da verdade? O que a poesia apresenta/representa/torna presente? Parece que o traço distintivo de poesia e pensamento está no modo de pertencimento de ambos à verdade: segundo a concepção escolástica da verdade, a poesia diz o que é falso, enquanto o pensamento lógico diz a verdade. E se verdade não for uma relação de adequação/concordância/ correção entre coisa e enunciado, mas sim o desvelamento do real no âmbito da linguagem? Nosso desafio futuro será investigar de que modo a verdade, entendida como desvelamento, se dá no dizer da poesia e no dizer do pensamento.

\section{Referências}

AGOSTINHO. [S.D] Soliloquiorum libri duo. Disponível em:

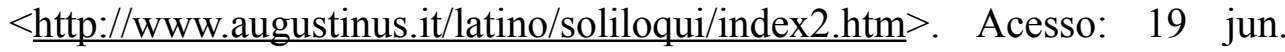
2020 .

AGOSTINHO, S. 1998. Solilóquios e a vida feliz. São Paulo: Paullus.

AQUINO, T. 2001. Suma Teológica. Volume I. São Paulo: Edições Loyola.

AQUINO, T. 2002. Suma Teológica. Volume II. São Paulo: Edições Loyola.

ARISTÓTELES. 2002. Metafísica. Tradução de Giovanni Reale. São Paulo: Edições Loyola.

ARISTÓTELES. 1984. Poética. Tradução de Eudoro de Sousa. In: Coleção Os Pensadores. Aristóteles. Organização de José Américo Motta Pessanha. São Paulo: Abril S.A. Cultural. 
CASTRO, M. A. (Org.). 2014. Convite ao pensar. Rio de Janeiro: Tempo Brasileiro.

ECO, U. 1994. Seis passeios pelos bosques da ficção. São Paulo: Companhia das Letras.

GADAMER, H-G. 2011. Verdade e método. Volume I. Petrópolis: Editora Vozes.

GALERA, F. 2013. Caminho, poética, acontecimento. Rio de Janeiro: Tempo Brasileiro.

GALERA, F. 2012. A compreensão da téchne como epistéme no Íon: um modelo hermenêutico de racionalidade. dEsEnrEdoS, Piauí, Ano IV, Número 14. pp. 1-18. Julho, agosto e setembro de 2012.

GALERA, F. 2014. O conceito de apropriação como questão fundamental do projeto hermenêutico de Paul Ricoeur. Niterói. 158 páginas. Dissertação (Mestrado). Universidade Federal Fluminense - UFF.

HEIDEGGER, M. 2008. Ser e tempo. 3. ed. Tradução de Marcia de Sá Cavalcante Schuback. Petrópolis: Vozes.

NICOLAS, M-J. 2001. Vocabulário da Suma Teológica. In: AQUINO, T. Suma Teológica. Volume I. São Paulo: Edições Loyola.

STANISLAVISKI, C. 1999. A preparação do ator. Rio de Janeiro: Civilização Brasileira. 